Article

\title{
Influence of Cooling Methods on the Behavior of Reactive Powder Concrete Exposed to Fire Flame Effect
}

\author{
Hadeel K. Awad \\ Department of Civil Engineering, University of Baghdad, Baghdad 10011, Iraq; \\ hadeel.kalid@coeng.uobaghdad.edu.iq or hadeel_k_awad@yahoo.com
}

Received: 7 February 2020; Accepted: 13 March 2020; Published: 20 March 2020

check for updates

\begin{abstract}
The construction of highly safe and durable buildings that can bear accident damage risks including fire, earthquake, impact, and more, can be considered to be the most important goal in civil engineering technology. An experimental investigation was prepared to study the influence of adding various percentages $0 \%, 1.0 \%$, and $1.5 \%$ of micro steel fiber volume fraction $\left(\mathrm{V}_{f}\right)$ to reactive powder concrete (RPC) — whose properties are compressive strength, splitting tensile strength, flexural strength, and absorbed energy - after the exposure to fire flame of various burning temperatures 300, 400 , and $500{ }^{\circ} \mathrm{C}$ using gradual-, foam-, and sudden-cooling methods. The outcomes of this research proved that the maximum reduction in mechanical properties is detected in case of $0 \%$ addition at burning temperature of $500{ }^{\circ} \mathrm{C}$ using sudden cooling to be $63.90 \%, 55.77 \%$ and $53.8 \%$ for compressive, splitting tensile, and flexural strength, respectively, while using $1.5 \%$ produced a modification in compressive strength, splitting tensile strength, and flexural strength to $6.67 \%, 4.15 \%$, and $7.00 \%$ respectively, and $7.10 \mathrm{kN} \cdot \mathrm{mm}$ for the absorbed energy for gradual cooling at $300{ }^{\circ} \mathrm{C}$. From the results, the adopted cooling methods can be ordered according to their negative influence by sudden, foam, and gradual, while the optimum percentage of $\left(\mathrm{V}_{f}\right)$ is $1.5 \%$ when burning at $300{ }^{\circ} \mathrm{C}$ for all methods of cooling. $1.0 \%$ is considered the optimum percentage for all burning temperatures that exceed $400{ }^{\circ} \mathrm{C}$ using sudden-cooling method.
\end{abstract}

Keywords: reactive powder concrete; micro steel fiber; fire flame; gradual cooling; foam cooling; sudden cooling

\section{Introduction}

Reactive powder concrete (RPC) is one of the most influential and evolved concrete technologies. This type of concrete is compatible for various kinds of intricate structures, such as bridges, large-span arched rooves, prestressed concrete structures, nuclear power stations, and more [1,2]. Fire-resistant execution of normal-strength concrete (NSC) is higher than that of RPC due to the specialty of the dense micro-structure of RPC which prevents pressure release from the core of concrete [3]. However, much research has shown that the incorporation of steel and polypropylene fibers yields better fire resistance [4]. Its modified properties increase the probability of using this type of concrete in fortified structures that are exposed to a high percentage of fire flame effect during their service life. Short steel fibers improve cracking performance and increase post-cracking ductility and energy dissipation capacity of structural elements. Using steel fibers in RPC can be considered very important when used under tension for the shear response of concrete beams due to the enhanced cracking performance of fiber reinforced concrete. There should be potential partial replacement of common steel stirrups with fibers, especially in cases where design criteria recommend a high transverse steel ratio that leads to short stirrup spacing. The shear strength and the fire resistivity of concrete elements with dense steel reinforcement would be very useful at certain burning temperatures [5-7]. 
Basically, fire influence should be considered in concrete structure design to avoid fire conceivable risk, because such an effect signifies the most critical conditions for both structures and buildings. Fire resistivity of RPC with different polypropylene and steel fibers content was studied by testing four columns (statically). After being exposed to fire for 30 and $60 \mathrm{~min}$, an investigation was carried out to study the performance of (RPC) columns at elevated temperature, by concentrating on the failure mechanism in fiber, residual strength, and spalling depth. The results showed that increasing steel fiber volume fraction or the presence of polypropylene fiber improves the fire resistance of the RPC columns exposed to fire flame [8]. Another investigation studied the influence of fire flame on the compressive strength of RPC reinforced by hooked steel fiber for various burning temperatures 300,400 , and $500{ }^{\circ} \mathrm{C}$. The burning duration for all burned RPC specimens was $60 \mathrm{~min}$. The tested specimens were reinforced by $3 \mathrm{~cm}$-long and $1100 \mathrm{MPa}$-yield strength hooked-end steel fiber with volume fraction of $0 \%, 1.0 \%$, and $1.5 \%$. Gradual and sudden-cooling processes were included. It was concluded that by increasing the burning temperature there was a decrease in the residual compressive strength for the RPC specimens of $0 \%$ steel fiber volume fraction at 300,400 , and $500{ }^{\circ} \mathrm{C}$ by $12.16 \%, 19.46 \%$, and $24.49 \%$, and $18.20 \%$, $27.77 \%$, and $36.07 \%$ for gradual cooling and sudden cooling, respectively. This reduction was modified by adding steel fiber; the $1.0 \%$ characterized the optimum response. Burning (RPC) that has non-zero steel fiber content up to $400{ }^{\circ} \mathrm{C}$ caused an increase in the residual compressive strength for a case of gradual cooling to be $4.37 \%$ and $6.25 \%$ for steel fiber volume fraction of $1 \%$ and $1.5 \%$, respectively. The negative influence of sudden-cooling method was directly proportional to both steel fiber volume fraction and burning temperature, which makes it the critical cooling method [9]. An experimental investigation on some residual mechanical properties of RPC (splitting tensile strength, fracture energy and compressive strength) exposed to high temperatures $\left(200\right.$ to $\left.600^{\circ} \mathrm{C}\right)$ using different percentages of steel and polypropylene fibers was considered. It was concluded that after exposure to $400{ }^{\circ} \mathrm{C}$, RPC specimens lose their original strength considerably. Moreover, fracture energy of RPC after exposure to $600{ }^{\circ} \mathrm{C}$ was still quite high [10]. The effect of fire flame on some properties of RPC slabs (flexural strength, modulus of elasticity, splitting tensile strength, and compressive strength) was investigated using many parametric studies such as slab thickness, temperature, burning duration, and steel reinforcement ratio. The results typically showed that when raising the temperature to $600{ }^{\circ} \mathrm{C}$ and $60 \mathrm{~min}$ burning duration, all the RPC specimens were spalled and significantly lost their mechanical properties. It was also concluded that using RPC slabs of $50 \mathrm{~mm}$ thickness was sufficient to resist exposure without spalling the upper surface of concrete at high temperature [11]. A study was done to explore the fire resistance of four steel fiber reinforced concrete (SFRC) beams after pre-impact loading. The beams were exposed to fire with a constant load after subjection to impact loadings. The failure patterns of the beams were observed. It was found that when using low-velocity impact load, the failure patterns of SFRC with the increase of steel fiber dosage are altered from shear type to bending type. When the impact energy is lower, the beam still shows good fire resistance and works in an elastic stage [12]. The effect of steel fibers with various aspect ratios on some mechanical properties of concrete was investigated after the exposure to high temperature reaching to $500{ }^{\circ} \mathrm{C}$ for $3 \mathrm{~h}$ in an electric furnace. It was noted that steel fiber-reinforced concrete compared to control concrete had a flexural toughness less affected by high temperature [13]. The behavior of RPC columns reinforced by fibers was studied after the exposure to fire flame for the period $2 \mathrm{~h}$ at one side and subjected to eccentric load. The results showed that columns lost from their load capacity and the best fire resistance of the column obtained when using a hybrid reinforced concrete with steel fiber RPC core and polypropylene fiber reactive powder concrete cover [14]. An experimental study was done to determine and evaluate the density and spalling behavior of RPC after exposure to actual fire flame at temperatures of $150{ }^{\circ} \mathrm{C}, 300{ }^{\circ} \mathrm{C}, 450{ }^{\circ} \mathrm{C}$, and $600^{\circ} \mathrm{C}$. The results showed that the densities of the RPC specimens increased when burned at $150^{\circ} \mathrm{C}$ compare to those at laboratory temperature. An obvious reduction in density was found for samples burned at $300{ }^{\circ} \mathrm{C}$ and $450{ }^{\circ} \mathrm{C}$. It was also noticed that there was a partial or complete spalling by about $20 \%$ for RPC burned at $600{ }^{\circ} \mathrm{C}$ [15]. The structural behavior of reinforced RPC beams exposed to fire flame and under service load was investigated. The beams 
consisted of hybrid fibers by 50\% steel fibers and 50\% polypropylene fibers with different volume fractions. The beams containing hybrid fibers resisted the failure concerning all test periods. The deflection during fire exposure increased with the increase of hybrid fiber content. Moreover, adding hybrid fibers improved the residual stiffness of fire-damaged beams [16].

\section{Materials and Methods}

The cement used in this study, which conforms Iraqi specification No.5/1984 [17] and ASTM C150-05 [18], was Al-Mass Ordinary Portland cement; its physical properties and chemical composition are listed in Table 1. For the adopted fine aggregate, the grain size distribution ranged from 150 to $600 \mu \mathrm{m}$; Table 2 illustrates the physical and chemical properties of the fine aggregate, which conforms to Iraqi specification No.45/1984 [19]. For the silica fume, the physical properties and chemical composition are shown in Table 3, which conforms to the requirements of ASTM C1240-03 [20]. SikaViscoCrete 5930 was the chemical admixture that was considered in this study as a super plasticizer, which meets the requirements of superplasticizer types G and F according to ASTM C494-05 [21]. The properties of superplasticizer are shown in Table 4 . In the current study, different percentage volume fraction $\left(\mathrm{V}_{f}\right)$ equal to $0 \%, 1 \%$, and $1.5 \%$ of micro steel fiber were adopted with high tensile of $1000 \mathrm{MPa}$, $0.6 \mathrm{~mm}$ in diameter, and $10 \mathrm{~mm}$ in length that to say an aspect ratio of $1 / \mathrm{d}=60$.

Table 1. Cement properties. L.O.I.: loss of ignition, IR: insoluble residue and L.S.F.: lime saturation factor.

\begin{tabular}{|c|c|c|c|c|}
\hline \multicolumn{2}{|c|}{ Properties } & $\begin{array}{r}\text { Result } \\
61.63\end{array}$ & $\begin{array}{l}\text { Iraqi Specification } \\
\text { No. } 5 \text { [17] Limits } \\
-\end{array}$ & $\begin{array}{c}\text { ASTM C150 [18] } \\
\text { Limits }\end{array}$ \\
\hline $\begin{array}{c}\text { Chemical } \\
\text { composition }(\%)\end{array}$ & $\begin{array}{l}\mathrm{CaO} \\
\mathrm{SiO}_{2} \\
\mathrm{Al}_{2} \mathrm{O}_{3} \\
\mathrm{Fe}_{2} \mathrm{O}_{3} \\
\mathrm{SO}_{3} \\
\mathrm{MgO} \\
\text { L.O.I. } \\
\text { I.R. } \\
\text { L.S.F. } \\
\mathrm{C}_{3} \mathrm{~S} \\
\mathrm{C}_{2} \mathrm{~S} \\
\mathrm{C}_{3} \mathrm{~A} \\
\mathrm{C}_{4} \mathrm{AF}\end{array}$ & $\begin{array}{c}61.63 \\
21.34 \\
4.29 \\
3.80 \\
2.11 \\
2.35 \\
2.20 \\
0.61 \\
0.49 \\
54.40 \\
20.92 \\
4.94 \\
11.56\end{array}$ & $\begin{array}{c}- \\
- \\
- \\
- \\
\leq 2.8 \text { If } \mathrm{C} 3 \mathrm{~A} \geq 5 \% \\
\leq 5.0 \% \\
\leq 4.0 \% \\
\leq 1.5 \% \\
0.66-1.02 \\
- \\
- \\
- \\
-\end{array}$ & $\begin{array}{c}\leq 3.0 \text { if } \mathrm{C} 3 \mathrm{~A} \leq 8 \% \\
\leq 6.0 \% \\
\leq 3.0 \% \\
\leq 0.75 \%\end{array}$ \\
\hline \multicolumn{2}{|c|}{$\begin{array}{l}\text { Setting time (Vicat's method) } \\
\text { Initial setting (min.) }\end{array}$} & $1: 25$ & $\geq 45 \mathrm{~min}$ & $\geq 45 \mathrm{~min}$ \\
\hline \multicolumn{2}{|c|}{ Final setting (hrs.) } & $5: 49$ & $\leq 10 \mathrm{~h}$ & $\leq 375 \mathrm{~min}$ \\
\hline \multicolumn{2}{|c|}{$\begin{array}{c}\text { Compressive strength }(\mathrm{MPa}) \\
3 \text { days }\end{array}$} & 17.3 & $\geq 15$ & $\geq 12$ \\
\hline \multicolumn{2}{|c|}{7 days } & 24.9 & $\geq 23$ & $\geq 19$ \\
\hline \multirow{2}{*}{\multicolumn{2}{|c|}{$\begin{array}{l}\text { Blaine surface area }\left(\mathrm{m}^{2} / \mathrm{kg}\right) \\
\text { Soundness (Auto clave Method) }(\%)\end{array}$}} & 301 & $\geq 230$ & $\geq 280$ \\
\hline & & 0.5 & $\leq 0.8$ & \\
\hline
\end{tabular}

Table 2. Fine aggregate physical and chemical properties.

\begin{tabular}{ccc}
\hline Property & Result & Iraq Specification No.45/1984 [19] \\
\hline Specific gravity & 2.63 & - \\
Material finer than $0.075 \mathrm{~mm}$ & 2.8 & $\leq 5$ \\
Sulphate $\mathrm{SO}_{3}(\%)$ & 0.19 & $\leq 0.5$ \\
Absorption (\%) & 1.09 & - \\
Soluble salts $(\%)$ & 0.06 & $\leq 0.1$ \\
\hline
\end{tabular}


Table 3. Silica fume physical properties and chemical composition.

\begin{tabular}{|c|c|c|}
\hline Composition & Content $\%$ & $\begin{array}{c}\text { ASTM } \\
\text { C1240-03 [20] Limits }\end{array}$ \\
\hline $\mathrm{SiO}_{2}$ & 92.6 & $\geq 85 \%$ \\
\hline $\mathrm{Al}_{2} \mathrm{O}_{3}$ & 0.21 & \\
\hline $\mathrm{Fe}_{2} \mathrm{O}_{3}$ & 0.04 & \\
\hline $\mathrm{MgO}$ & 0.03 & \\
\hline $\mathrm{CaO}$ & 0.81 & \\
\hline $\mathrm{SO}_{3}$ & 0.35 & \\
\hline $\mathrm{K}_{2} \mathrm{O}$ & 0.06 & \\
\hline L.O.I. & 3.7 & $\leq 6 \%$ \\
\hline \multicolumn{3}{|c|}{ Physical Properties } \\
\hline & \multirow{4}{*}{\multicolumn{2}{|c|}{$\begin{array}{c}\text { Powder } \\
16,000 \mathrm{~m}^{2} / \mathrm{kg} \\
2.17 \\
\text { Gray }\end{array}$}} \\
\hline & & \\
\hline $\mathrm{Sp}$ & & \\
\hline & & \\
\hline
\end{tabular}

Table 4. Properties of superplasticizer used.

\begin{tabular}{cccc}
\hline Form & Basis & Appearance & Relative Density \\
\hline Viscous liquid & $\begin{array}{c}\text { Aqueous solution of } \\
\text { modified } \\
\text { polycarboxylate }\end{array}$ & Turbid liquid & $1.08 \mathrm{~g} / 1 \mathrm{t} \pm 0.005$ \\
\hline
\end{tabular}

The adopted mix proportions of RPC are presented in Table 5. After mixing the RPC, it was cast in $100 \times 100 \times 100 \mathrm{~mm}$ cubic molds for compressive strength tests which were done according to B.S.1881: part 116 [22]. Regarding splitting tensile strength, $100 \times 200 \mathrm{~mm}^{2}$ cylinder molds were cast satisfying the ASTM C496/C496M-11 [23] and $100 \times 100 \times 400 \mathrm{~mm}^{3}$ prisms were cast for flexural strength according to the ASTM C293-11 [24] and load-deflection tests. An average of three samples was considered for each test.

Table 5. The mix proportions used for the RPC specimens. W/b: water to binder ratio.

\begin{tabular}{cccccc}
\hline $\begin{array}{c}\text { Concrete Mix } \\
\text { Symbol }\end{array}$ & $\mathbf{W} / \mathbf{b}$ & $\begin{array}{c}\text { Cement } \\
\left(\mathbf{k g} / \mathbf{m}^{3}\right)^{*}\end{array}$ & $\begin{array}{c}\text { Fine Aggregate } \\
\left(\mathbf{k g} / \mathbf{m}^{3}\right)^{*}\end{array}$ & $\begin{array}{c}\text { Silica Fume } \\
\left(\mathbf{k g} / \mathbf{~ m}^{3}\right)^{*}\end{array}$ & $\mathbf{V}_{f} \%$ \\
\hline$S$ & 0.2 & 860 & 1020 & 205 & 0 \\
$S_{1}$ & 0.2 & 860 & 1020 & 205 & 1 \\
$S_{2}$ & 0.2 & 860 & 1020 & 205 & 1.5 \\
\hline
\end{tabular}

${ }^{*} \mathrm{~kg}$ per $\mathrm{m}^{3}$ of concrete volume.

The RPC specimens were burned in a fire flame burner, which is supplied with direct fire flame torches to ensure actual fire flame conditions. Three groups of specimens were set in the fire flame burner according to the corresponding temperature. Two steps were included in the burning process. These are temperature elevation state up to the adopted temperature 300,400 , and $500{ }^{\circ} \mathrm{C}$ and steady-state temperature for one hour. A thermocouple device was used to measure the temperature inside the fire flame burner at both elevated and steady-state stages as shown in Figure 1. The adopted cooling methods used to cool the RPC specimens to laboratory temperature were gradual, foam, and sudden cooling, (see Figure 2). In the gradual-cooling method, the burning specimens were left to cool gradually with no external effect (under the conditions of room temperature), while the burning specimens were suddenly immerged in a container filled with water for the case of sudden-cooling method. Powder foam was considered to achieve the conditions of the third adopted method (foam cooling); the burning specimens in this case were completely covered with foam. 


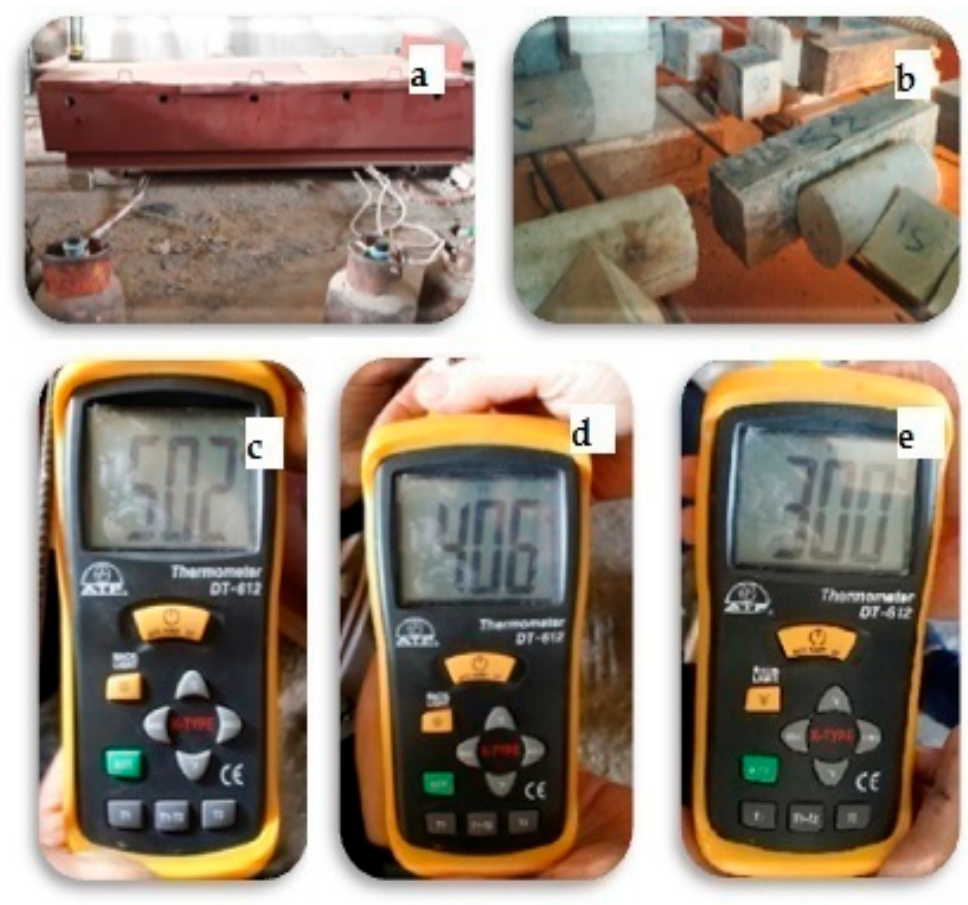

Figure 1. Burning process: (a) Burning furnace setup; (b) Samples inside the furnace; (c) Thermocouple device at $500{ }^{\circ} \mathrm{C} ;\left(\right.$ d) Thermocouple device at $400{ }^{\circ} \mathrm{C}$; (e) Thermocouple device at $300{ }^{\circ} \mathrm{C}$.
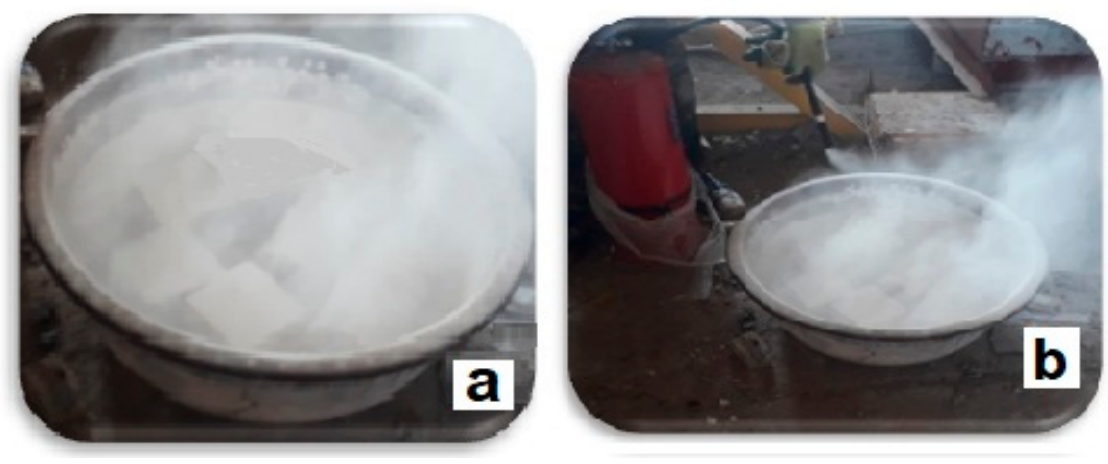

Figure 2. Cooling methods (a) Sudden-cooling; (b) Foam-cooling method.

\section{Results and Discussions}

Basically, the discussion comprises the effect of three parameters $\left(\mathrm{V}_{f}\right.$ percentage, burning temperature, and cooling methods). The influence of these parameters was investigated regarding the behavior of the considered mechanical properties (compressive strength, splitting tensile strength, and absorbed energy).

\subsection{Compressive Strength}

A concrete test press machine was used to perform the compressive strength test for cubic specimens according to the B.S.1881: part 116 [22], some of the tested cubs are shown in Figure 3. Regarding the compressive strength of (RPC), all the considered steel fiber volume fraction percentages showed a reduction in this property for all the considered burning temperatures except those of $1.0 \%$ and $1.5 \%$ at burning temperature $300{ }^{\circ} \mathrm{C}$ for gradual and foam cooling as shown in Figure 4 and illustrated in Table 6. Burning at $300^{\circ} \mathrm{C}$ caused no significant change in the traditional influence of $\mathrm{V}_{f}$ percentage upon the compressive strength (direct proportion) for all the considered cooling methods as shown in Figure 5a. This behavior was valid for burning temperatures of 400 and $500{ }^{\circ} \mathrm{C}$ in cases of 
gradual and foam cooling, while there was a reduction in the amount of compressive strength in cases of $1.0 \%$ and $1.5 \%$ in sudden-cooling method, as shown in Figure $5 b, c$. These facts were also proved by other research [25-28].

The same trend was detected for all the considered cooling methods: as the burning temperature increased, the obtained percentage reduction increased, as illustrated in Table 6 and Figure 6.

In general, a compatible behavior was attainted for both gradual and foam cooling. The worst case was represented by $0 \%$ fiber volume fraction where the reduction reached to $33.5 \%$ and $42.65 \%$ respectively at $500{ }^{\circ} \mathrm{C}$, as illustrated in Table 7 , while there was a modification in the behavior in the case of $1.0 \%$ and $1.5 \%$ to be $3.13 \%, 6.67 \%$, and $0.57 \%, 3.14 \%$ for gradual and foam cooling, respectively at $300{ }^{\circ} \mathrm{C}$, (see Table 7). Other modification was obtained in the case of gradual cooling for $1.5 \%$ at $400{ }^{\circ} \mathrm{C}$ to be $1.6 \%$, as shown in Figure $6 \mathrm{a}$.

In the case of sudden cooling, there was no modification for all the considered burning temperatures and percentages of fiber volume fraction. The relationship between the percentage reduction and the burning temperature proved that the case of $0 \%$ fiber volume fraction was the wariest case in sudden-cooling method; the reduction reached $63.9 \%$ at $500{ }^{\circ} \mathrm{C}$ (see Table 7).

In the case of burning at $500{ }^{\circ} \mathrm{C}$, it was noted that some reactive powder concrete samples with no steel fiber volume fraction spalled in some positions into small pieces.

At burning temperature $300{ }^{\circ} \mathrm{C}$, there was no change in the effect of fiber volume fraction percentage for sudden-cooling methods from that of gradual and foam-cooling methods on the percentage reduction of compressive strength; $1.0 \%$ fiber volume fraction was more affected by the percentage reduction than that of $1.5 \%$ to be $7.92 \%$ and $6.61 \%$ respectively in the case of sudden-cooling method, while the percentage volume fraction of $1.5 \%$ was more affected on the percentage reduction than that of $1.0 \%$ for burning temperatures 400 and $500{ }^{\circ} \mathrm{C}$ as shown in Table 7, due to the influence of differences between the thermal expansion of concrete and steel fiber to be $10 \times 10^{-6} /{ }^{\circ} \mathrm{C}$ and $7.2 \times 10^{-6} /{ }^{\circ} \mathrm{C}$, respectively. This effect became more significant as the burning temperature rose over $400^{\circ} \mathrm{C}$.

The reduction was also affected by the increase of steel fiber volume fraction percentage and method of cooling (sudden can be considered to be the critical method, according to the obtained results) to be $9.0 \%, 13.74 \%$, and $28.7 \%$ for gradual, foam, and sudden at $500{ }^{\circ} \mathrm{C}$ with $1.5 \%$ fiber volume fraction, as shown in Figure 6 and Table 7.

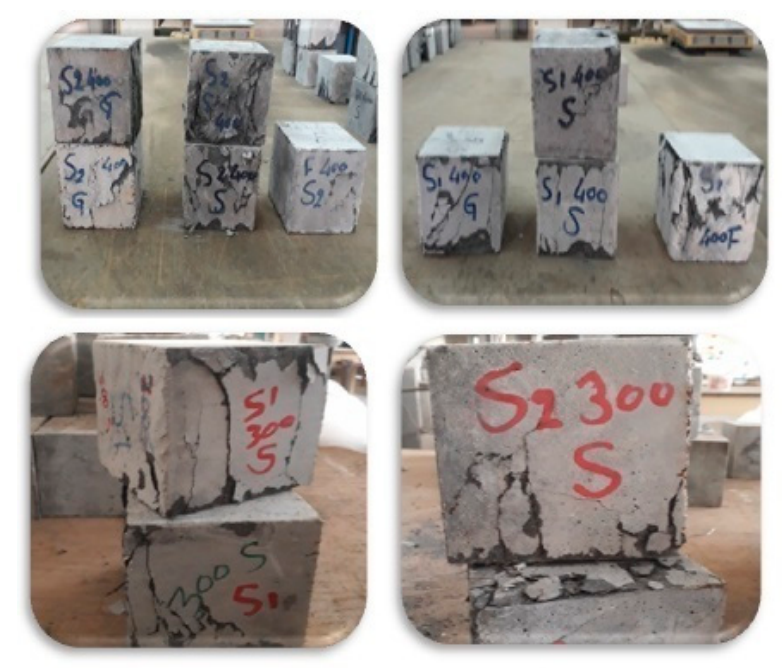

Figure 3. RPC samples at different burning temperatures and steel fiber volume fraction percentage after compressive strength test. 


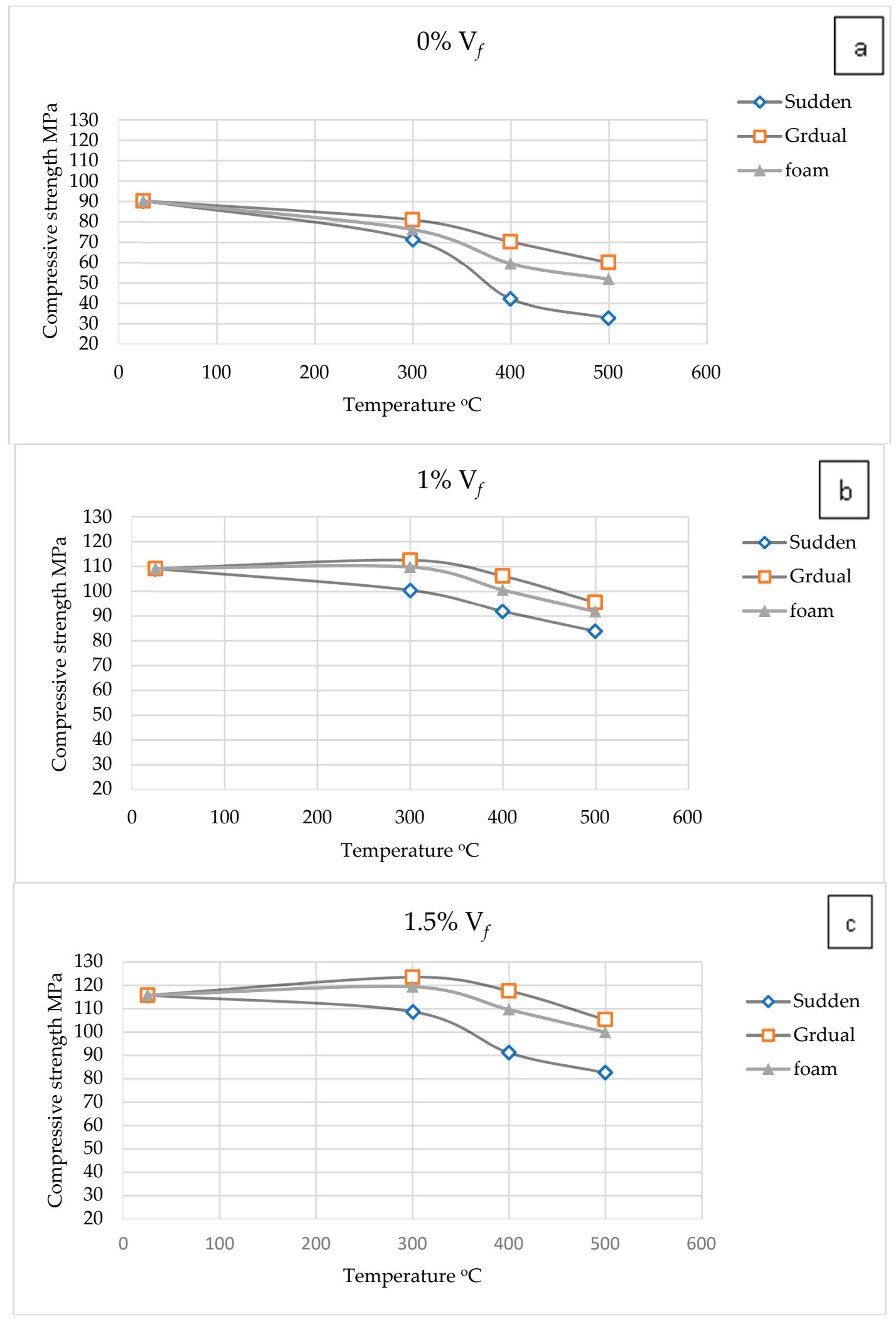

Figure 4. Compressive strength concerning all burning temperature and cooling methods: (a) For 0\% $\mathrm{V}_{f} ;(\mathbf{b})$ For $1.0 \% \mathrm{~V}_{f}$; and (c) For $1.5 \% \mathrm{~V}_{f}$. 
Table 6. Compressive strength results concerning all types of cooling for the adopted (RPC) mixes.

\begin{tabular}{ccccc}
\hline \multirow{2}{*}{ Type of Cooling } & $\begin{array}{c}\text { Burning } \\
\text { Temperature }\left({ }^{\circ} \mathbf{C}\right)\end{array}$ & $\mathbf{S ~ 0 \%}$ & $\mathbf{S}_{\mathbf{1}} \mathbf{1 . 0} \%$ & $\mathbf{S}_{\mathbf{2}} \mathbf{1 . 5} \%$ \\
\cline { 3 - 5 } & & 90.3 & 109.09 & 115.64 \\
Gradual & 25 & 81.00 & 112.50 & 123.36 \\
& 400 & 70.22 & 106.13 & 117.50 \\
& 400 & 60.04 & 95.45 & 105.23 \\
\hline \multirow{3}{*}{ Foam } & 500 & 90.30 & 109.09 & 115.64 \\
& 25 & 76.20 & 109.71 & 119.28 \\
& 300 & 59.40 & 100.41 & 109.45 \\
& 400 & 51.80 & 91.72 & 99.75 \\
\hline \multirow{3}{*}{ Sudden } & 500 & 90.30 & 109.09 & 115.65 \\
& 25 & 71.40 & 100.45 & 108.70 \\
& 300 & 42.04 & 91.81 & 91.02 \\
\end{tabular}

Table 7. Compressive strength percentage reduction concerning all types of cooling for the adopted (RPC) mixes.

\begin{tabular}{ccccc}
\hline \multirow{2}{*}{ Type of Cooling } & $\begin{array}{c}\text { Burning } \\
\text { Temperature }\left({ }^{\circ} \mathbf{C}\right)\end{array}$ & $\mathbf{S}$ 0\% & $\mathbf{S}_{\mathbf{1}} \mathbf{1 . 0} \%$ & $\mathbf{S}_{\mathbf{2}} \mathbf{1 . 5} \%$ \\
\cline { 3 - 5 } & & 10.30 & -3.13 & -6.67 \\
\multirow{3}{*}{ Gradual } & 300 & 22.23 & 2.71 & -1.60 \\
& 400 & 33.50 & 12.50 & 9.00 \\
\hline \multirow{2}{*}{ Foam } & 500 & 15.61 & -0.57 & -3.14 \\
& 300 & 34.22 & 7.96 & 5.36 \\
& 400 & 42.64 & 15.92 & 13.74 \\
\hline \multirow{3}{*}{ Sudden } & 500 & 20.93 & 7.92 & 6.61 \\
& 300 & 53.44 & 15.83 & 21.29 \\
\end{tabular}




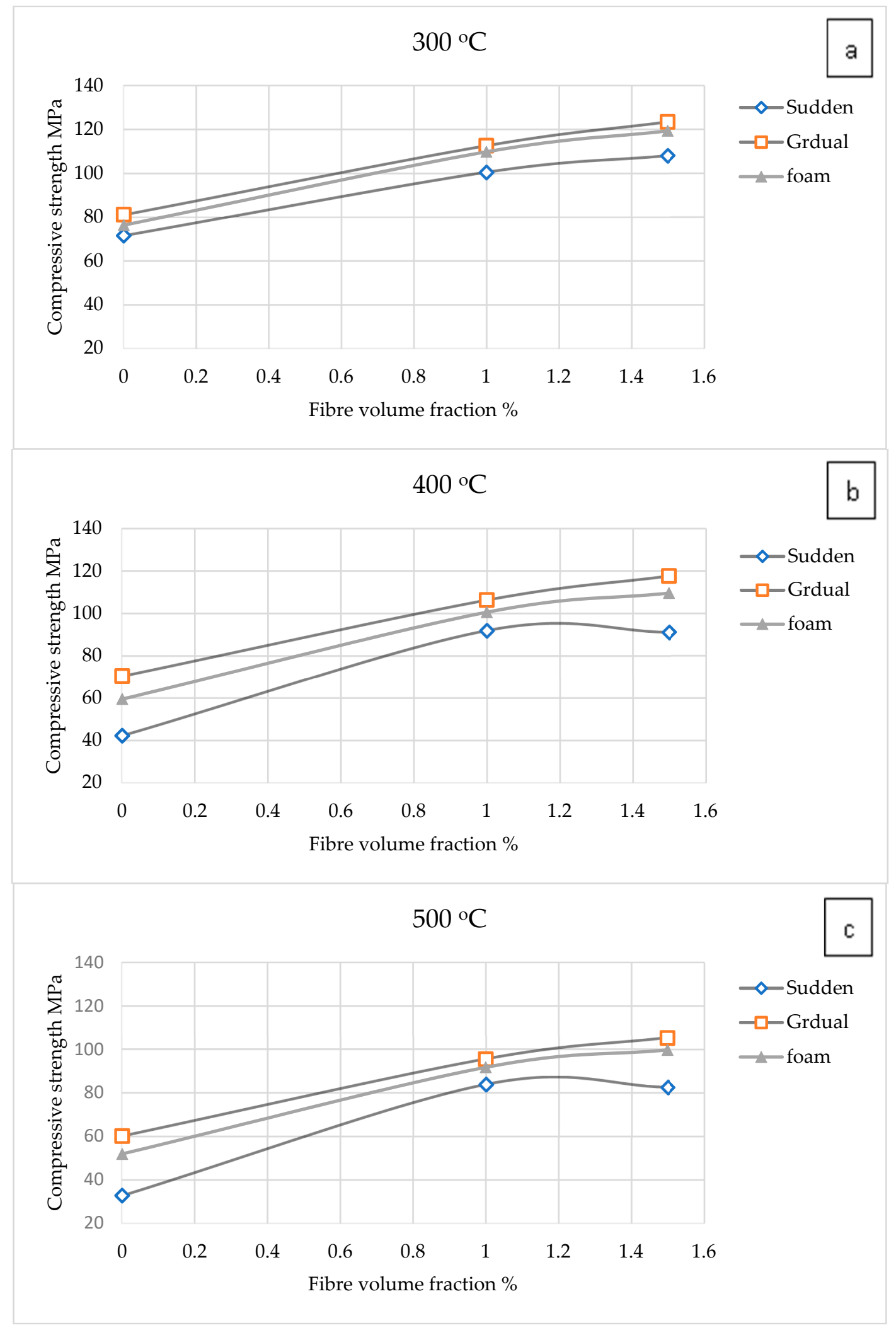

Figure 5. Compressive strength for various (RPC) specimens and cooling methods: (a) At burning temperature $300^{\circ} \mathrm{C}$; (b) At burning temperature $400{ }^{\circ} \mathrm{C}$; and (c) At burning temperature $500{ }^{\circ} \mathrm{C}$. 


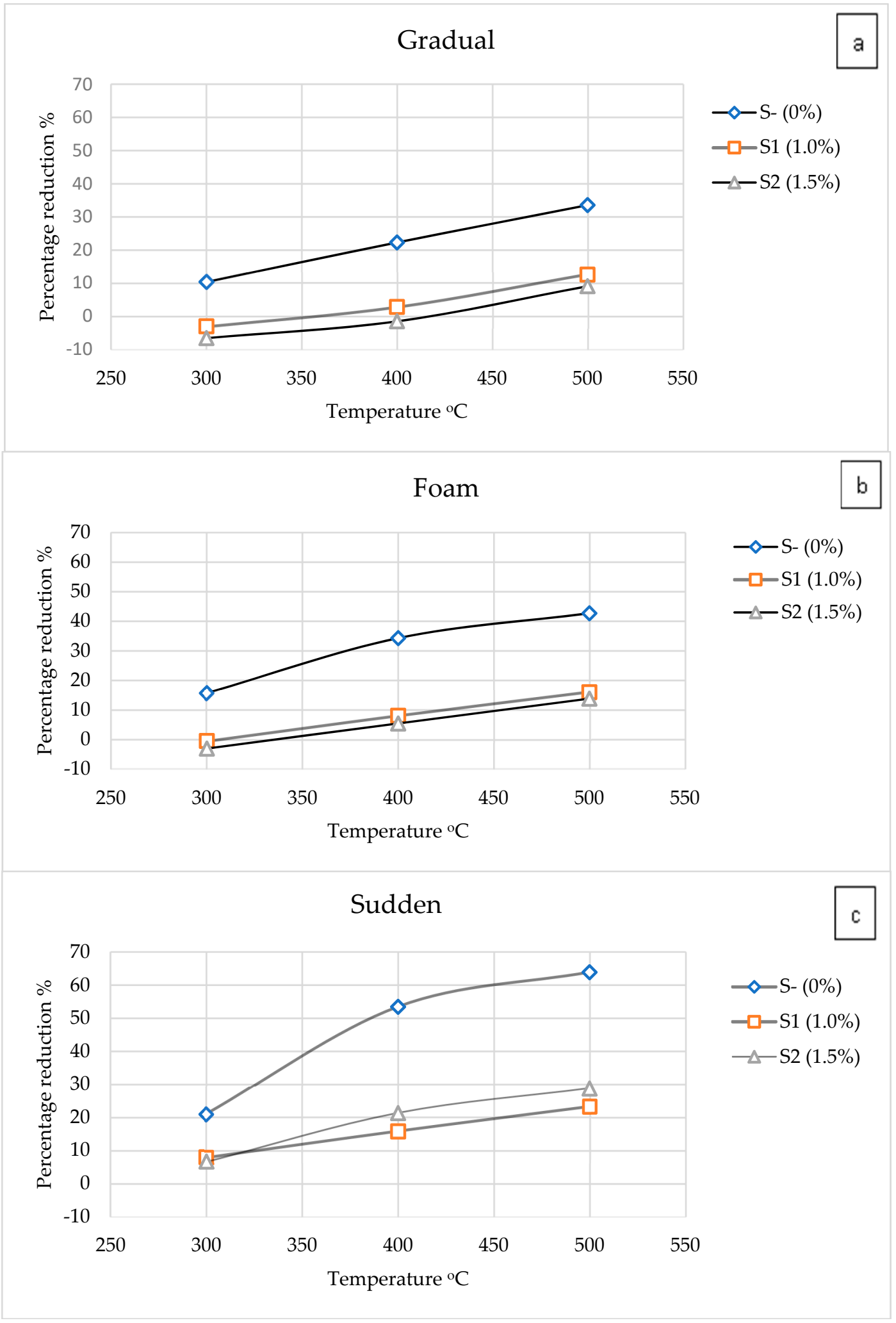

Figure 6. Percentage reduction in compressive strength concerning all burning temperature and various (RPC) specimens: (a) Gradual cooling; (b) Foam cooling; and (c) Sudden cooling. 


\subsection{Splitting Tensile Strength}

The burned cylindrical specimens were tested to evaluate the splitting tensile strength of the RPC according to the ASTM C496/C496M-17 [23]. All the tested specimens were symmetrically divided as shown in Figure 7.

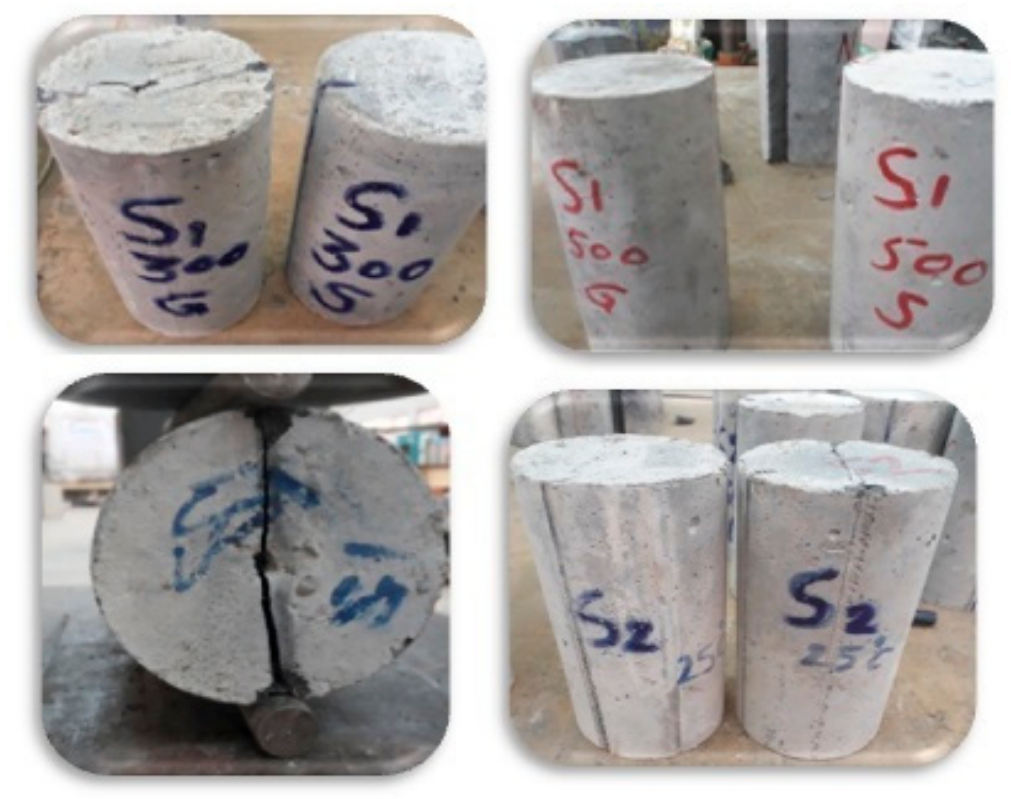

Figure 7. RPC samples at different burning temperatures and steel fiber volume fraction percentage after splitting tensile strength test.

It is well known that the percentage of steel fiber volume fraction has a highly significant effect on splitting tensile strength along with the compressive strength. The influence of steel fiber volume fraction percentage in the case of splitting tensile strength seems to be compatible with its effect upon the compressive strength as shown in Figure 8; this was compatible with other studies [26,27], even those that used adopted heat effect, not fire exposer. The obtained splitting tensile strength for $1.0 \%$ fiber volume fraction reached to $10.40 \%, 10.09 \%$, and $9.63 \% \mathrm{MPa}$ for gradual, foam, and sudden-cooling methods, respectively, at burning temperature $300^{\circ} \mathrm{C}$, while it reached $11.01,10.69$ and $10.11 \mathrm{MPa}$ at the same burning temperature in case of $1.5 \%$ fiber volume fraction for gradual, foam, and sudden-cooling methods, respectively, as exhibited in Table 8.

The outcomes concerning the impact of the burning temperatures proved that this effect directly increases especially for $0 \%$ of fiber volume fraction, as shown in Figure 9, the values of splitting tensile strength reached to $4.93,4.50$, and $4.08 \mathrm{MPa}$ for $0 \%$ fiber volume fraction at burning temperature $500^{\circ} \mathrm{C}$ for gradual, foam, and sudden-cooling methods, respectively, as illustrated in Table 8 .

To investigate the influence of cooling methods on the behavior of splitting tinsel strength, the percentage reduction in this property was studied. Regarding sudden cooling, the most critical case was characterized by 1.5 and $0 \%$ fiber volume fraction at burning temperature $500{ }^{\circ} \mathrm{C}$ reaching to $53.39 \%$ and $55.77 \%$ respectively, as shown in Figure 10c and Table 9.

In the case of foam-cooling method, there was a modification in the percentage of reduction to reach $-0.07 \%$ and $-1.1 \%$ for volume fraction $1.0 \%$ and $1.5 \%$, respectively, at burning temperature $300{ }^{\circ} \mathrm{C}$ and the worst reduction regarding foam cooling reached $42.53 \%$ and $51.1 \%$ for $1.0 \%$ and $0 \%$ volume fraction, respectively, at burning temperature $500^{\circ} \mathrm{C}$, as shown in Figure 10b and Table 9 .

The optimal attitude regarding the reduction in splitting tensile strength was presented by gradual-cooling followed by foam-cooling method, which appears to throw out the values of the modification in the percentage reduction in case of gradual cooling use to reach $-3.17 \%$ and $-4.15 \%$ for volume fraction $1.0 \%$ and $1.5 \%$ respectively at burning temperature $300{ }^{\circ} \mathrm{C}$, while the reduction 
reached to $37.63 \%$ and $34.10 \%$ for volume fraction $1.0 \%$ and $1.5 \%$ respectively at burning temperature $500{ }^{\circ} \mathrm{C}$, as illustrated in Table 9 and Figure 10a.

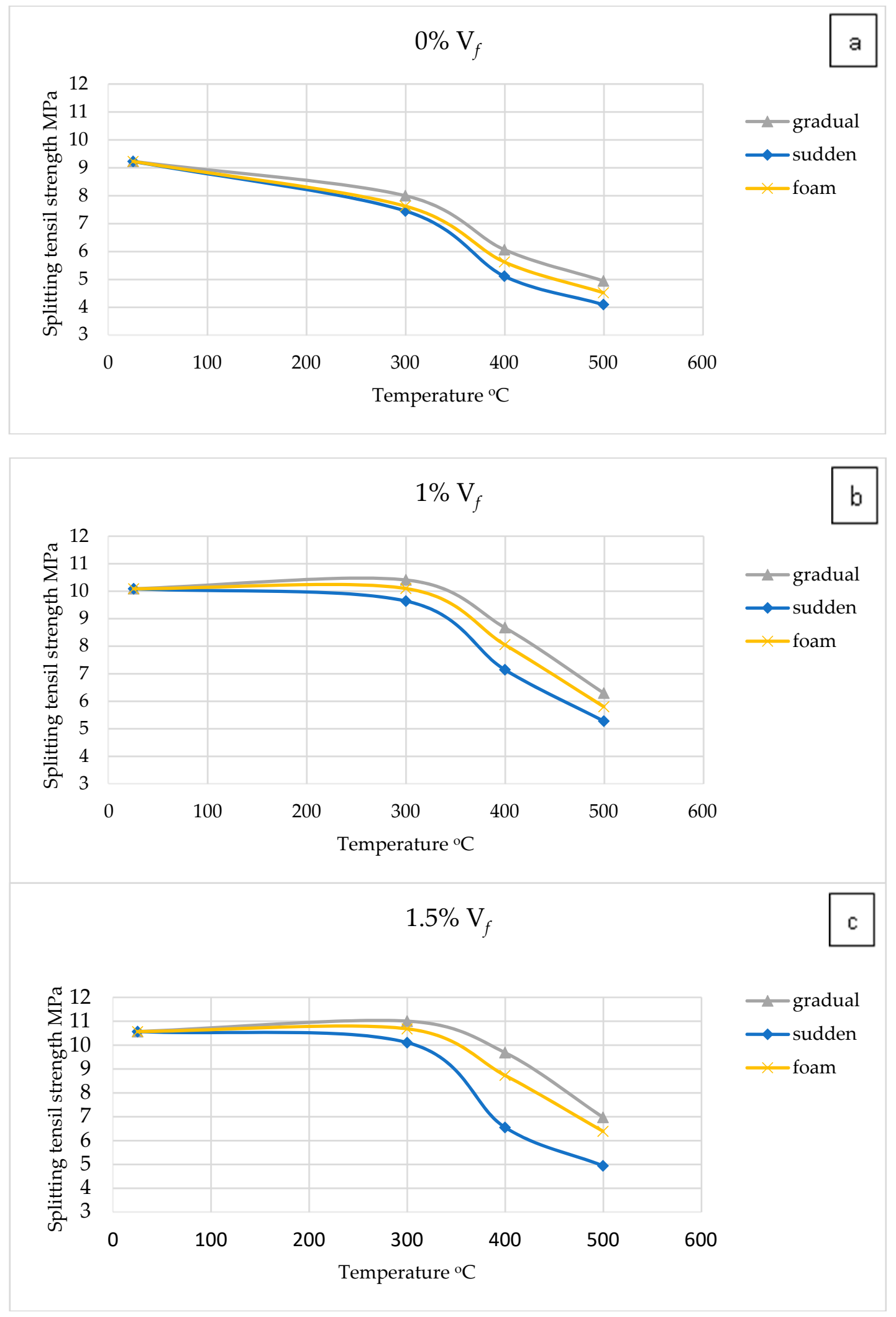

Figure 8. Splitting tensile strength concerning all burning temperatures and cooling methods: (a) For $0 \% \mathrm{~V}_{f}$; (b) For $1.0 \% \mathrm{~V}_{f}$; and (c) For $1.5 \% \mathrm{~V}_{f}$. 
Table 8. Splitting tensile strength results concerning all types of cooling for the adopted RPC mixes.

\begin{tabular}{ccccc}
\hline \multirow{2}{*}{ Type of Cooling } & $\begin{array}{c}\text { Burning Temperature } \\
\left({ }^{\circ} \mathbf{C}\right)\end{array}$ & \multicolumn{3}{c}{ Splitting Tensile Strength (MPa) } \\
\cline { 2 - 4 } & 25 & $\mathbf{S ~ 0 \%}$ & $\mathbf{S}_{\mathbf{1}} \mathbf{1 . 0} \%$ & $\mathbf{S}_{\mathbf{2}} \mathbf{1 . 5} \%$ \\
\hline \multirow{3}{*}{ Gradual } & 300 & 9.22 & 10.08 & 10.57 \\
& 400 & 7.99 & 10.40 & 11.01 \\
& 500 & 6.05 & 8.67 & 9.69 \\
Foam & 25 & 4.93 & 6.29 & 6.97 \\
\hline \multirow{3}{*}{ Sudden } & 300 & 9.22 & 10.08 & 10.57 \\
& 400 & 7.61 & 10.09 & 10.69 \\
& 500 & 5.61 & 8.05 & 8.73 \\
& 25 & 4.50 & 5.79 & 6.38 \\
\hline & 300 & 9.22 & 10.08 & 10.57 \\
& 400 & 7.44 & 9.63 & 10.11 \\
& 500 & 5.10 & 7.14 & 6.54 \\
\end{tabular}

Table 9. Splitting tensile strength percentage reduction concerning all types of cooling for the adopted RPC mixes.

\begin{tabular}{ccccc}
\hline \multirow{2}{*}{ Type of Cooling } & Burning & \multicolumn{3}{c}{ Percentage Reduction } \\
\cline { 3 - 5 } & & $\mathbf{S ~ 0 \%}$ & $\mathbf{S}_{\mathbf{1}} \mathbf{1 . 0} \%$ & $\mathbf{S}_{\mathbf{2}} \mathbf{1 . 5} \%$ \\
\hline \multirow{3}{*}{ Temperature $\left({ }^{\circ} \mathbf{C}\right)$} & 13.37 & -3.17 & -4.15 \\
& 300 & 34.39 & 14.03 & 8.38 \\
& 400 & 46.55 & 37.63 & 34.10 \\
\hline \multirow{2}{*}{ Foam } & 500 & 17.43 & -0.07 & -1.10 \\
& 300 & 39.18 & 20.18 & 17.44 \\
& 400 & 51.16 & 42.53 & 39.68 \\
\hline \multirow{2}{*}{ Sudden } & 500 & 19.31 & 4.42 & 4.36 \\
& 300 & 44.71 & 29.20 & 38.12 \\
\end{tabular}

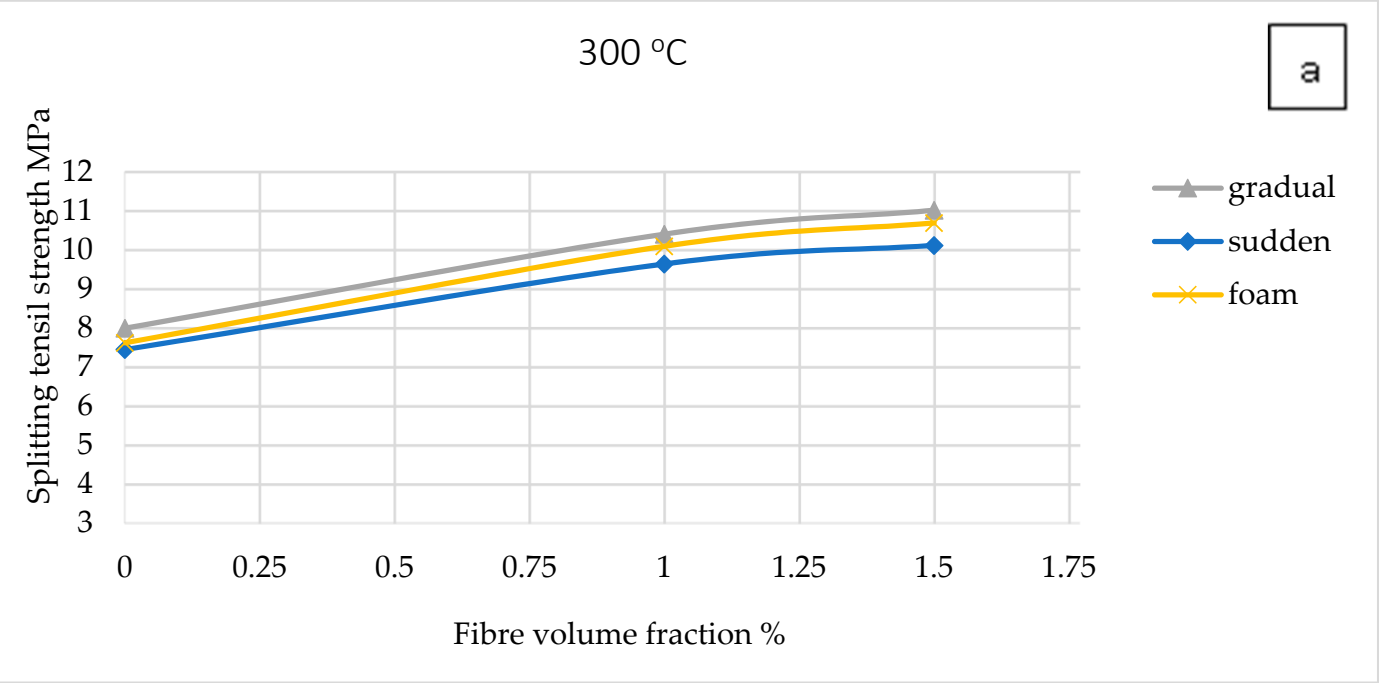

Figure 9. Cont. 


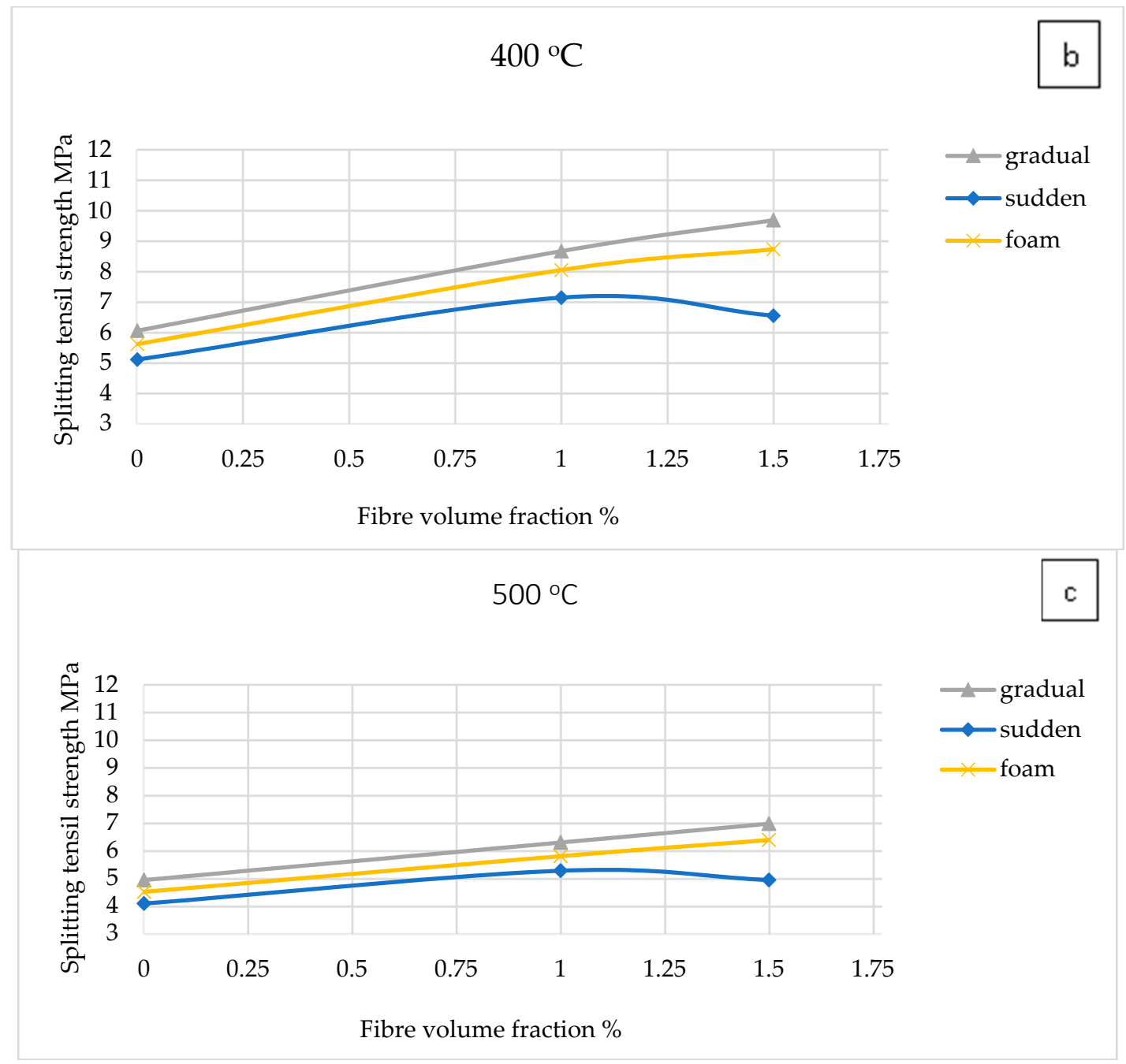

Figure 9. Splitting tensile strength for various (RPC) specimens and cooling methods: (a) At burning temperature $300^{\circ} \mathrm{C}$; (b) At burning temperature $400{ }^{\circ} \mathrm{C}$; and (c) At burning temperature $500{ }^{\circ} \mathrm{C}$.

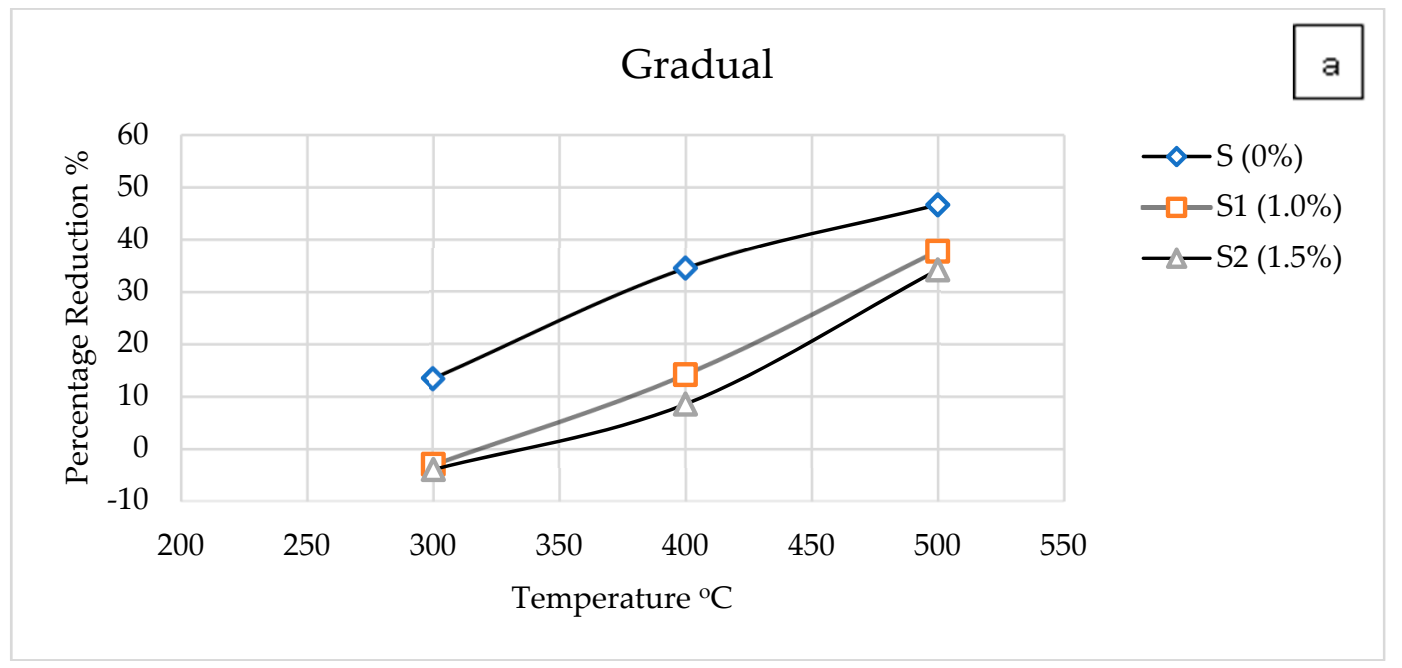

Figure 10. Cont. 


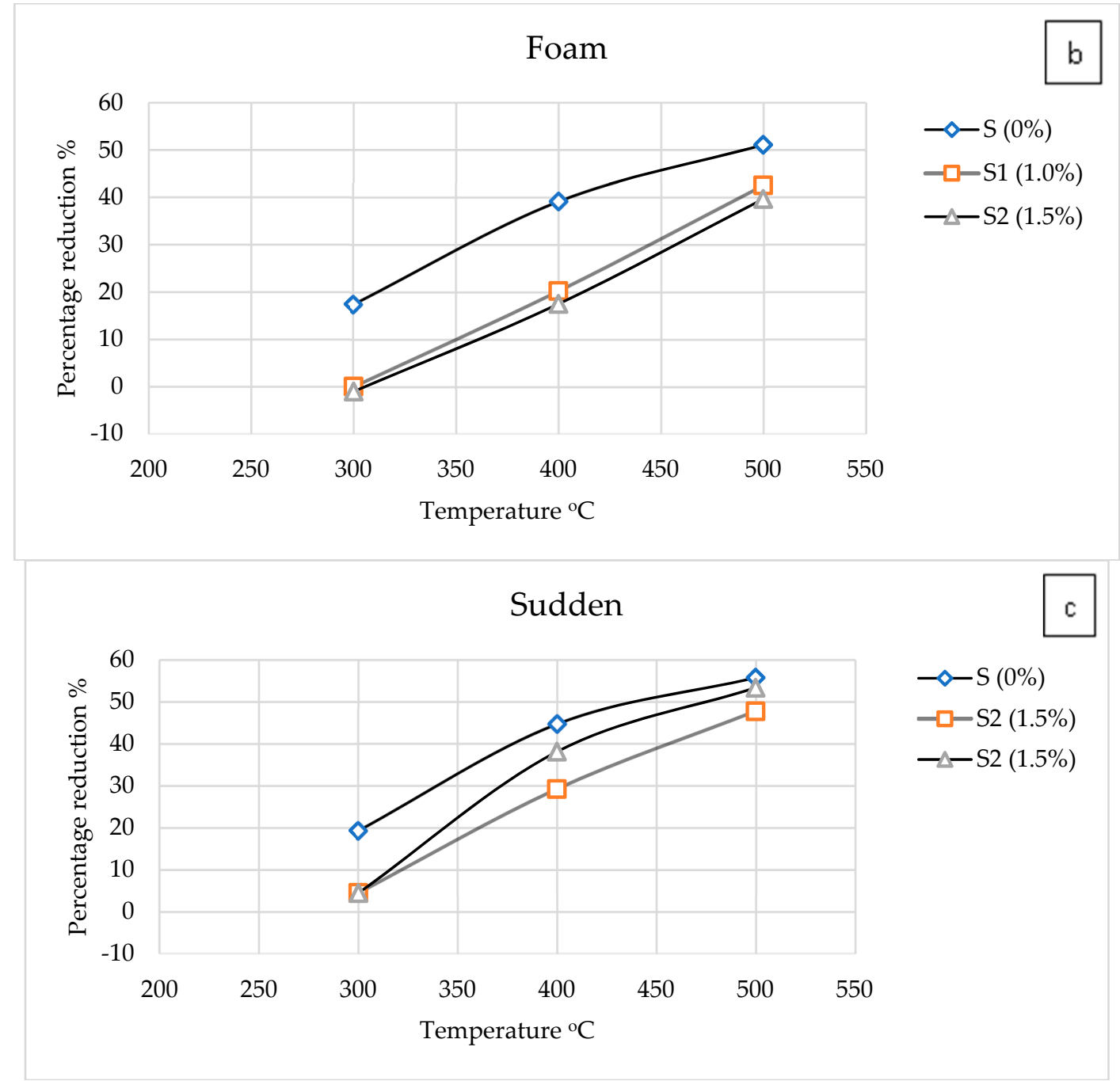

Figure 10. Percentage reduction in splitting tensile strength concerning all burning temperature and various (RPC) specimens: (a) Gradual cooling; (b) Foam cooling; and (c) Sudden cooling.

\subsection{Flexural Strength and Absorbed Energy}

Flexural strength and load-deflection tests were performed using $100 \times 100 \times 400 \mathrm{~mm}^{3}$ prisms that are set in a simply supported condition affected by a concentrated load at mid-span, as shown in Figure 11. To achieve better understanding of the effect of cooling methods on load-deflection behavior, three parameters were considered (failure load, ultimate deflection, and absorbed energy). In the case of sudden-cooling method, burning specimens at $400{ }^{\circ} \mathrm{C}$ or more caused a reduction in the modified effect of steel fiber volume fraction percentage upon the failure load, ultimate deflection, and absorbed energy. There was a reflexive behavior at burning temperature $300^{\circ} \mathrm{C}$ where the influence of increasing steel fiber volume fraction percentage caused an enhancement upon the considered parameters. Regarding gradual and foam-cooling methods, there was a direct correlation between the increasing of steel fiber volume fraction percentage and the studied parameters (failure load, ultimate deflection, and absorbed energy) for all considered burning temperatures 300, 400, and $500^{\circ} \mathrm{C}$, as exhibited in Figures 12 and 13 . 


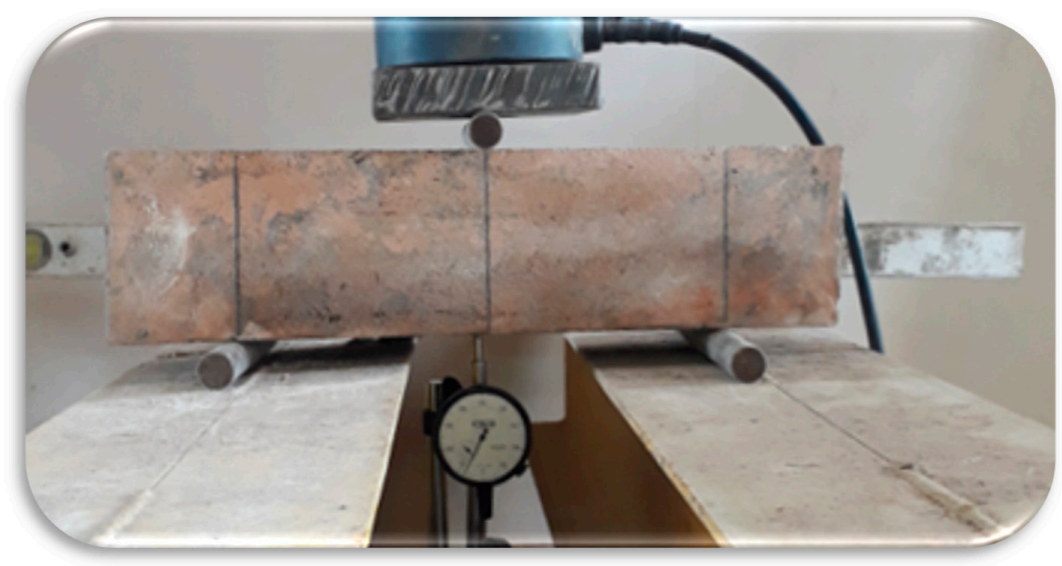

Figure 11. A sample of deflection determination for $1.0 \% \mathrm{~V}_{f}$ at $400{ }^{\circ} \mathrm{C}$ with gradual-cooling method.

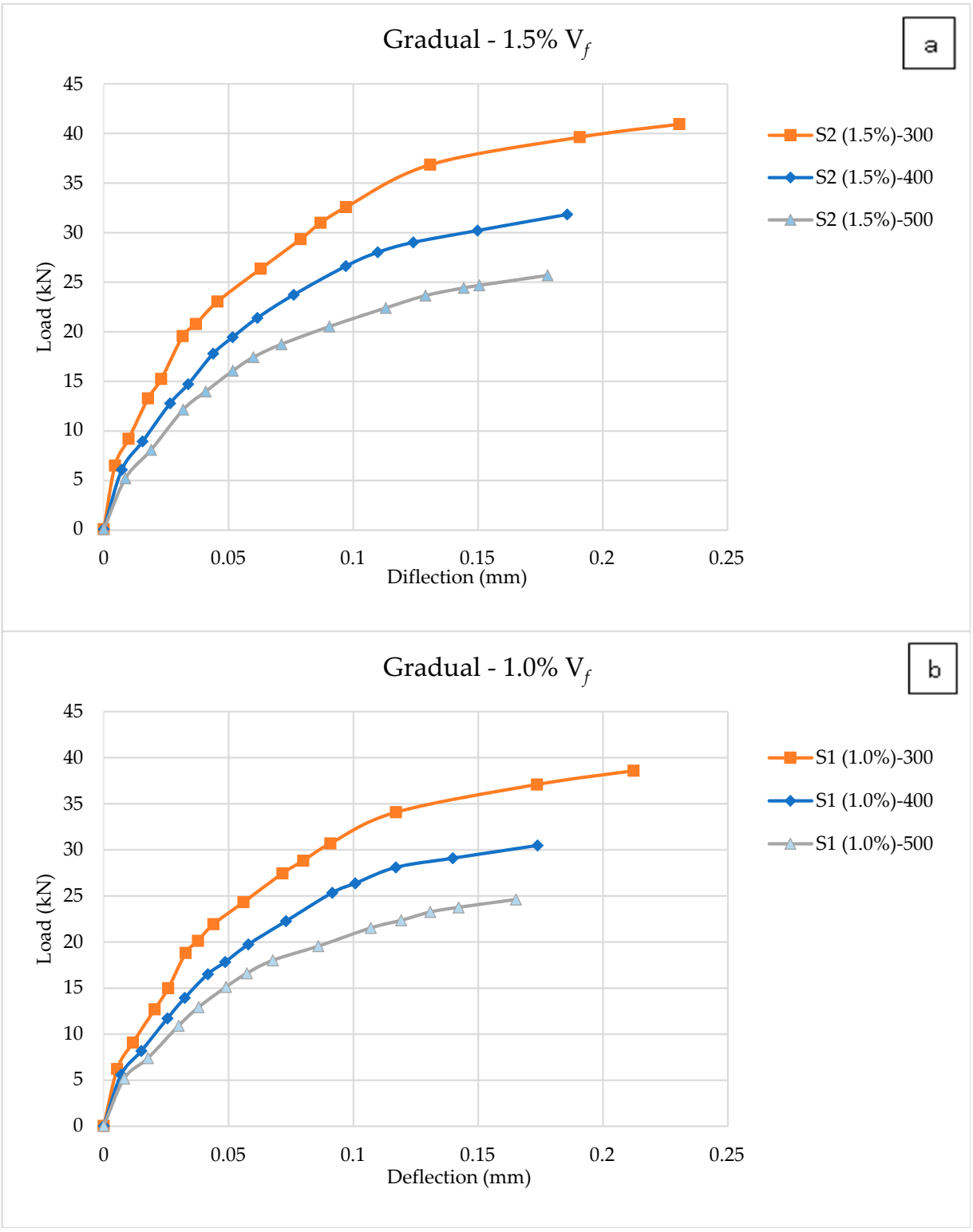

Figure 12. Load-Deflection curves concerning gradual cooling at different burning temperatures: (a) For $1.5 \% \mathrm{~V}_{f}$; and (b) For $1.0 \% \mathrm{~V}_{f}$. 


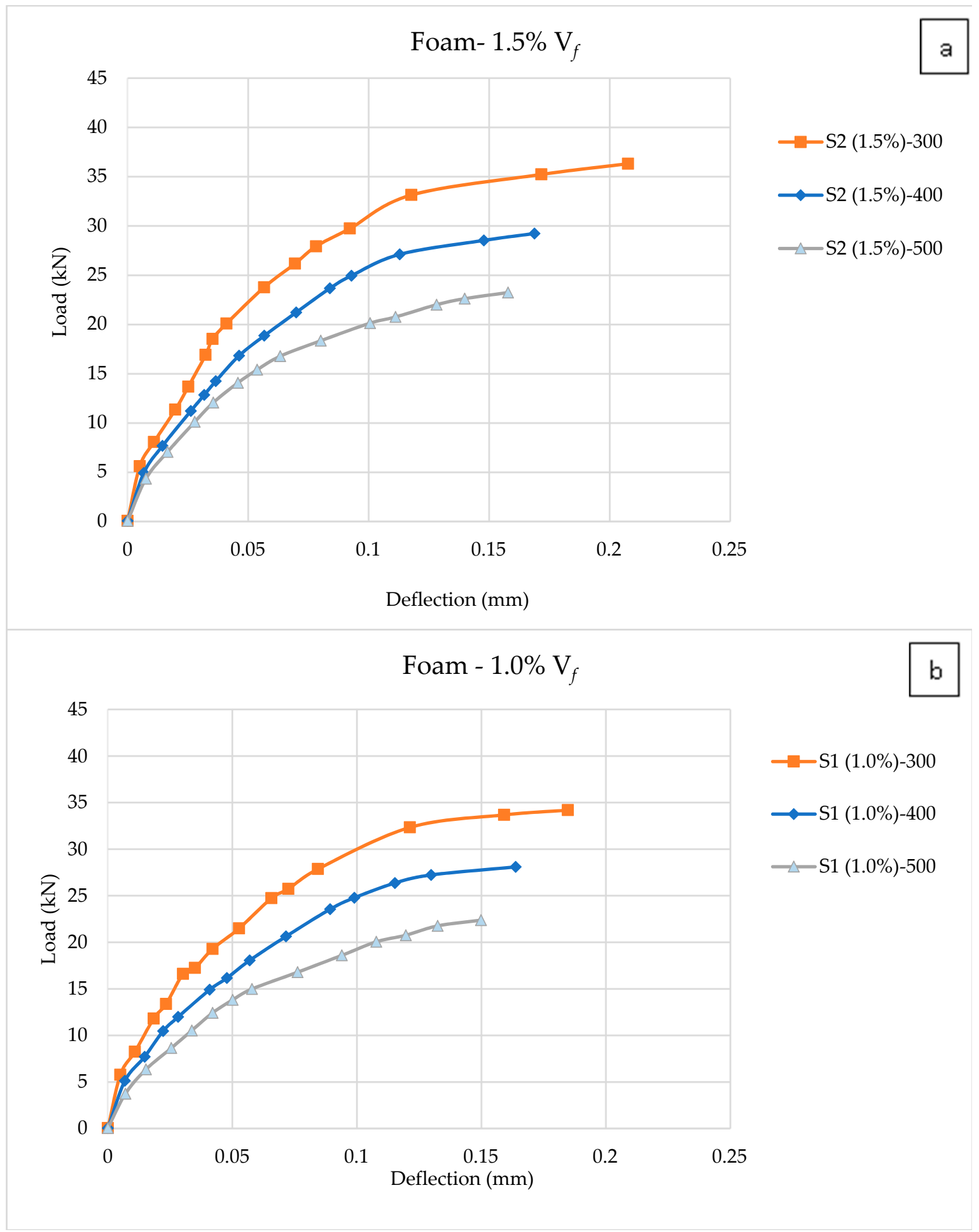

Figure 13. Load-Deflection curves concerning foam cooling at different burning temperatures: (a) For $1.5 \% \mathrm{~V}_{f}$; and (b) For $1.0 \% \mathrm{~V}_{f}$.

It was detected that steel fiber volume fraction of $1.5 \%$ presented the optimum behavior at burning temperature $300{ }^{\circ} \mathrm{C}$, the absorbed energies reached $7.19,5.69$, and $4.79 \mathrm{kN} . \mathrm{mm}$ and for $1.0 \%$ they were $6.13,4.76$, and 3.96 for gradual, foam, and sudden cooling, respectively. This fact differed as the burning temperature rose over $400{ }^{\circ} \mathrm{C}$, where steel fiber volume fraction of $1.0 \%$ presented the optimum behavior for sudden-cooling method; the absorbed energies were 2.93 and $2.11 \mathrm{kN} . \mathrm{mm}$ at 
burning temperatures 400 and $500{ }^{\circ} \mathrm{C}$, respectively, as illustrated in Table 10 and shown in Figure 14 . The outcomes of load-deflection test proved that gradual-cooling method caused a limited reduction on the overall characteristics of load-deflection (failure load, ultimate deflection, and absorbed energy).

Table 10. Absorbed energy for all the adopted (RPC) mixes.

\begin{tabular}{|c|c|c|}
\hline RPC Mix & Burning Temperature $\left({ }^{\circ} \mathrm{C}\right)$ & Absorbed Energy $(\mathrm{kN} \cdot \mathrm{mm})$ \\
\hline \multirow{3}{*}{ Gradual $-\mathrm{S}_{2} 1.5 \%$} & 300 & 7.19 \\
\hline & 400 & 4.32 \\
\hline & 500 & 3.28 \\
\hline \multirow{3}{*}{ Gradual $-S_{1} 1.0 \%$} & 300 & 6.13 \\
\hline & 400 & 3.92 \\
\hline & 500 & 2.94 \\
\hline \multirow{3}{*}{ Foam $-S_{2} 1.5 \%$} & 300 & 5.69 \\
\hline & 400 & 3.55 \\
\hline & 500 & 2.59 \\
\hline \multirow{3}{*}{ Foam $-S_{1} 1.0 \%$} & 300 & 4.76 \\
\hline & 400 & 3.29 \\
\hline & 500 & 2.29 \\
\hline \multirow{3}{*}{ Sudden $-S_{2} 1.5 \%$} & 300 & 4.79 \\
\hline & 400 & 2.79 \\
\hline & 500 & 1.80 \\
\hline \multirow{3}{*}{ Sudden $-S_{1} 1.0 \%$} & 300 & 3.96 \\
\hline & 400 & 2.93 \\
\hline & 500 & 2.11 \\
\hline
\end{tabular}

The flexural strength test was done according to the ASTM C293-11 [24] and its results are illustrated in Table 11. The behavior of flexural strength was compatible with that of splitting tensile strength since the optimal attitude regarding the reduction in flexural strength was presented by gradual cooling followed by foam-cooling method that appears to throw out the values of the modification in the percentage reduction to reach $-3.68 \%$ and $-7.00 \%$ for volume fraction $1.0 \%$ and $1.5 \%$, respectively at burning temperature $300{ }^{\circ} \mathrm{C}$ in the case of using gradual cooling; at burning temperature $500{ }^{\circ} \mathrm{C}$ the reduction reached $27.57 \%$ and $26.57 \%$ for volume fraction $1.0 \%$ and $1.5 \%$ respectively by using the same cooling method, while the maximum percentage reduction reached $45.36 \%$ and $53.8 \%$ for burning temperature $500{ }^{\circ} \mathrm{C}$ using sudden-cooling method, as illustrated in Table 12 .

Table 11. Flexural strength results concerning all types of cooling for the adopted (RPC) mixes.

\begin{tabular}{ccccc}
\hline \multirow{2}{*}{ Type of Cooling } & Burning & \multicolumn{3}{c}{ Flexural Strength (MPa) } \\
\cline { 3 - 5 } & & $\mathbf{S ~ 0 \%}$ & $\mathbf{S}_{\mathbf{1}} \mathbf{1 . 0} \%$ & $\mathbf{S}_{\mathbf{2}} \mathbf{1 . 5 \%}$ \\
\hline \multirow{3}{*}{ Gradual } & 25 & 10.78 & 13.60 & 14.00 \\
& 300 & 10.15 & 14.10 & 14.98 \\
& 400 & 8.81 & 12.20 & 12.74 \\
Foam & 500 & 7.58 & 9.85 & 10.28 \\
\hline \multirow{2}{*}{ Sudden } & 300 & 9.61 & 13.70 & 14.53 \\
& 400 & 7.46 & 11.01 & 11.69 \\
& 500 & 6.50 & 8.96 & 9.29 \\
\hline
\end{tabular}




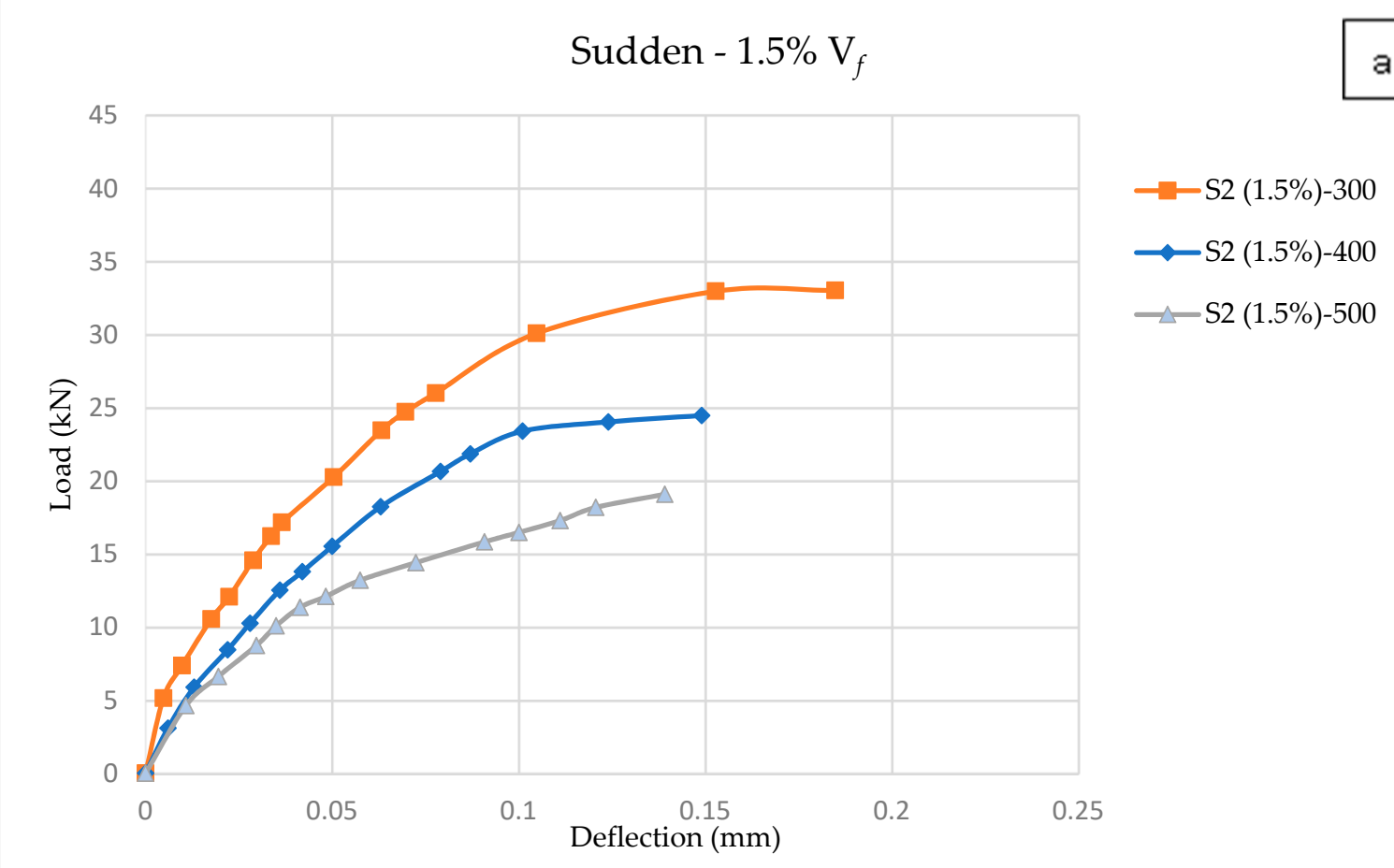

Sudden $-1.0 \% \mathrm{~V}_{f}$

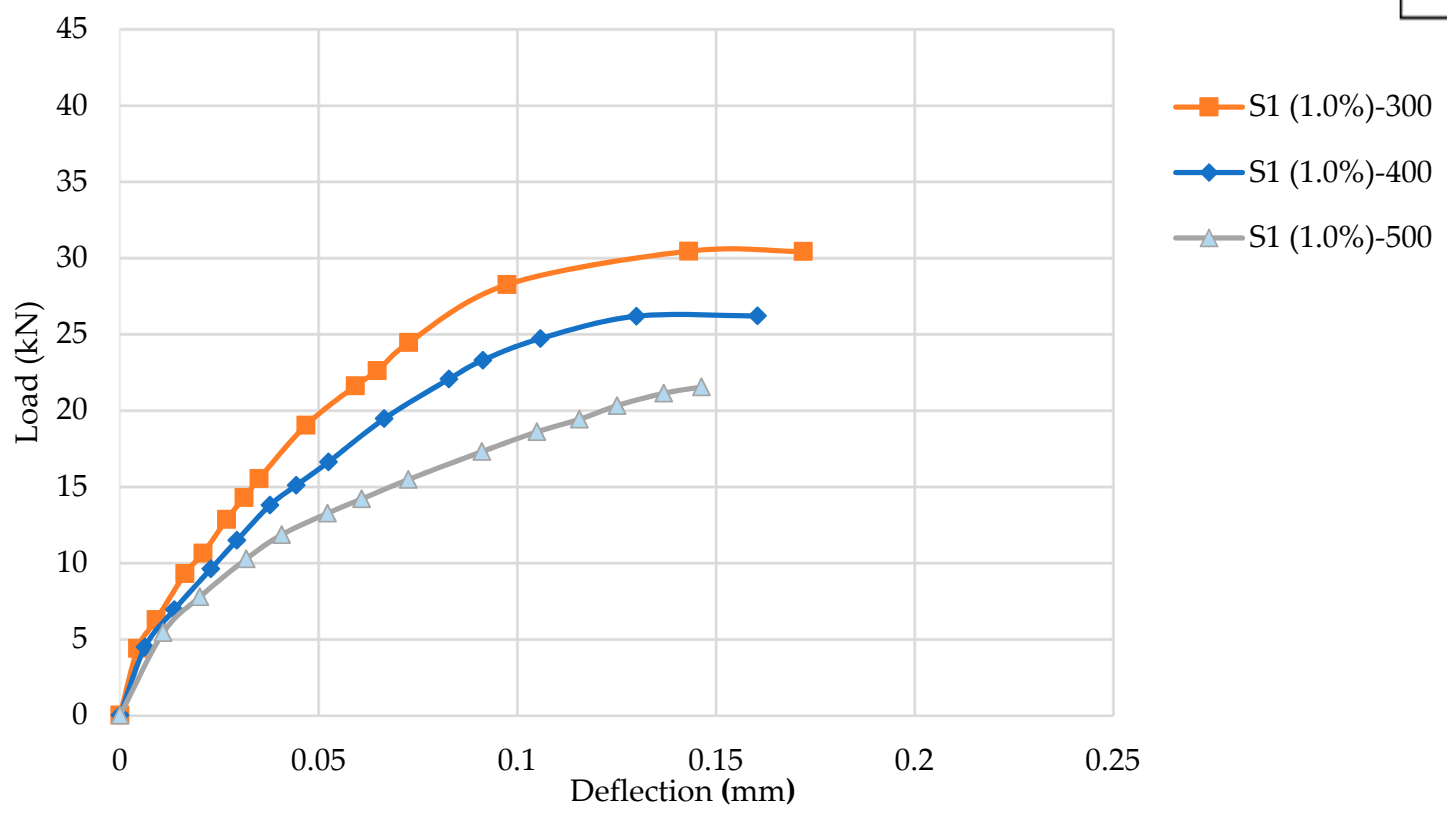

Figure 14. Load-Deflection curves concerning sudden cooling at different burning temperatures: (a) For $1.5 \% \mathrm{~V}_{f}$; and (b) For $1.0 \% \mathrm{~V}_{f}$. 
Table 12. Flexural strength percentage reduction concerning all types of cooling for the adopted (RPC) mixes.

\begin{tabular}{ccccc}
\hline \multirow{2}{*}{ Type of Cooling } & $\begin{array}{c}\text { Burning } \\
\text { Temperature }\left({ }^{\circ} \mathbf{C}\right)\end{array}$ & $\mathbf{3}$ P\% & $\mathbf{S}_{\mathbf{1}} \mathbf{1 . 0} \%$ & $\mathbf{S}_{\mathbf{2}} \mathbf{1 . 5 \%}$ \\
\cline { 3 - 5 } & 300 & 5.84 & -3.68 & -7.00 \\
\multirow{3}{*}{ Gradual } & 400 & 18.27 & 10.29 & 9.00 \\
& 500 & 29.68 & 27.57 & 26.57 \\
\hline \multirow{2}{*}{ Foam } & 300 & 10.85 & -0.74 & -3.79 \\
& 400 & 30.79 & 19.04 & 16.50 \\
\multirow{3}{*}{ Sudden } & 500 & 39.70 & 34.12 & 33.64 \\
& 300 & 17.72 & 10.44 & 5.50 \\
& 400 & 48.89 & 22.87 & 30.00 \\
\end{tabular}

\section{Conclusions}

From the obtained results, the main conclusions can be extracted as follows:

1. The greatest modified behavior for specimens burned at $300{ }^{\circ} \mathrm{C}$ can be gained using steel fiber volume fraction $1.5 \%$, regardless of the cooling method.

2. Gradual-cooling method caused less negative effect upon the considered properties (compressive strength, splitting tensile strength, flexural strength, and absorbed energy) than the other cooling methods (sudden and foam).

3. The largest negative influence upon the studied mechanical properties was detected in the case of sudden cooling compared to gradual cooling, while the effect of foam cooling was in between.

4. Regarding sudden-cooling method, steel volume fraction $1.0 \%$ presented the perfect choice for burning temperatures exceeding $400^{\circ} \mathrm{C}$. It reduces the damage influence in the original properties after exposure to fire effect.

5. The case of no steel fiber volume fraction presents the worst case regarding all burning temperatures compared to other percentages of steel fiber volume fraction used.

6. $\mathrm{RPC}$ specimens of no steel fiber volume fraction spalled when burning over $500{ }^{\circ} \mathrm{C}$.

Funding: This research received no external funding.

Acknowledgments: The author would like to express her appreciation and sincere gratitude for the sustenance provided by Department of Civil Engineering/University of Baghdad including Construction Material and Structure laboratories. Finally, the author wishes to acknowledge her colleges, Shatha D. Mohammed and Rawaa $\mathrm{K}$. Abood for their assistant and advice.

Conflicts of Interest: The author declares no conflict of interest.

\section{References}

1. Wasan, Z.M.; Nesreen, B.N.; Shatha, D.M.; Nada, M.F. Attenuation Coefficient of Reactive Powder Concrete Using Different Energies. Int. J. Adv. Res. 2016, 4, 72-82.

2. Shatha, D.M.; Wasan, Z.M.; Nesreen, B.N.; Nada, M.F. Investigating the influence of gamma ray energies and steel fibre on attenuation properties of reactive powder concrete. Nucl. Sci. Technol. 2017, 28, 153.

3. Kodur, V.K.R. Fire resistance design guidelines for high strength concrete columns. In Proceedings of the ASCE/SFPE Specialty Conference of Designing Structures for Fire and JFPE, Baltimore, MD, USA, 30 September-1 October 2003; pp. 1-11.

4. Lau, A.; Anson, M. Effect of high temperatures on high performance steel fiber reinforced concrete. Cem. Concr. Res. 2006, 36, 1698-1707. [CrossRef]

5. Chalioris, C.E.; Sfiri, E.F. Shear Performance of Steel Fibrous Concrete Beams. Procedia Eng. 2011, 14, 2064-2068. [CrossRef] 
6. Chalioris, C.E.; Panagiotopoulos, T.A. Flexural analysis of steel fiber-Reinforced concrete members. Comput. Concr. 2018, 22, 11-25. [CrossRef]

7. Chalioris, C.E.; Kosmidou, P.K.; Karayannis, C.G. Cyclic Response of Steel Fiber Reinforced Concrete Slender Beams; an Experimental Study. Materials 2019, 12, 1398. [CrossRef] [PubMed]

8. Rungrawee, W.; Daniel, N.R.; Withit, P.; Thuc, N.N.; Phoonsak, P. Fire Resistance Performance of Reactive Powder Concrete Columns. Eng. J. 2018, 22, 67-82.

9. Rawaa, K.A.; Hadeel, K.A.; Shatha, D.M. Fire flame effect on the compressive strength of reactive powder concrete using different methods of cooling. In Proceedings of the 2nd International Conference on Sustainable Engineering Techniques, Baghdad, Iraq, 6-7 March 2019.

10. Gai-Fei, P.; Yi-Rong, K.; Yan-Zhu, H.; Xiao-Ping, L.; Qiang, C. Experimental Research on Fire Resistance of Reactive Powder Concrete, Hindawi Publishing Corporation. Adv. Mater. Sci. Eng. 2012, 2012, 860303. [CrossRef]

11. Samir, A.M.; Farah, A.A. Behavior of Reactive Powder Concrete Slabs Exposed to Fire Flame. Int. J. Civ. Eng. Technol. 2015, 6, 126-138.

12. Liu, J.; Renbo, Z.; Guoqin, D.; Xiuli, D. Fire resistance of steel fiber reinforced concrete beams after low-Velocity impact loading. Fire Saf. J. 2018, 98, 24-37.

13. Augusto, C.S.; Priscila, S.M.; Elaine, C.S.; Paulo, R.R.; Maria, T.P.; Paulo, R.C. Effect of High Temperature on the Mechanical Properties of Steel Fiber-Reinforced Concrete. Fibers 2019, 7, 100. [CrossRef]

14. Hasanain, A.S.; Nameer, A.A. The Fire Exposure Effect on Hybrid Reinforced Reactive Powder Concrete Columns. Civ. Eng. J. 2020, 6, 363-374.

15. Zainab, S.R.; Jariah, M.J.; Mohd, R.M.; Mohammed, M.K. Density and Spalling behavior of Reactive Powder Concrete after Exposure to Fire Flame. In Proceedings of Innovative Research and Industrial Dialogue; University Teknikal Malaysia Melaka-UTeM: Melaka, Malaysia, 2018.

16. Al-Attar, A.A.; Abdulrahman, M.B.; Hamada, H.M.; Tayeh, B.A. Investigating the behavior of hybrid fiber-reinforced reactive powder concrete beams after exposure to elevated temperatures. J. Mater. Res. Technol. 2019. [CrossRef]

17. Iraq Standard Specification (IQS) No.5-1984. Portland Cement; Central Agency for Standardization and Quality Control: Baghdad, Iraq, 1984.

18. American Society for Testing and Materials (ASTM) C150-2007. Standard Specification for Portland Cement; ASTM International: West Conshohocken, PA, USA, 2007.

19. Iraq standard specification (IQS) No.45-1984. Aggregate from Natural Sources for Concrete and Building Construction; Central Agency for Standardization and Quality Control: Baghdad, Iraq, 1984.

20. American Society for Testing and Materials (ASTM) C1240-2003. Standard Specification for Use of Silica Fume as a Mineral Admixture in Hydraulic Cement Concrete, Mortar, and Grout; ASTM International: West Conshohocken, PA, USA, 2003.

21. American Society for Testing and Materials (ASTM) C494/C494M-2005. Standard Specification for Chemical Admixtures for Concrete; ASTM International: West Conshohocken, PA, USA, 2005.

22. British Standard Institution, B.S.1881: Part 116-1983. Methods for Determination of Compressive Strength of Concrete Cubes; British Standards Institution: London, UK, 1983.

23. American Society for Testing and Materials (ASTM) C496-/C496M-2011. Standard Test Method for Splitting Tensile Strength for Cylindrical Concrete Specimens; ASTM International: West Conshohocken, PA, USA, 2011.

24. American Society for Testing and Materials (ASTM) C293-11. Standard Test Method for Flexural Strength of Concrete (Using Simple Beam with Center-Point Loading); ASTM International: West Conshohocken, PA, USA, 2011.

25. Tai, Y.S.; Pan, H.H.; Kung, Y.N. Mechanical properties of steel fiber reinforced reactive powder concrete following exposure to high temperature reaching $800^{\circ} \mathrm{C}$. Nucl. Eng. Des. 2011, 241, 2416-2424. [CrossRef]

26. Muhammad, A.; Xiaomeng, H.; Wenzhong, Z.; Raja, R.H. Effect of Fibers on High-Temperature Mechanical Behavior and Microstructure of Reactive Powder Concrete. Materials 2019, 12, 329. [CrossRef]

27. Alaa, A.B. Influence of Elevated Temperatures on the Behavior of Economical Reactive Powder Concrete. J. Civ. Eng. Res. 2013, 3, 89-97. [CrossRef] 
28. Wenzhong, Z.; Haiyan, L.; Ying, W. Compressive behavior of hybrid fiber-reinforced reactive powder concrete after high temperature. Mater. Des. 2012, 41, 403-409.

(C) 2020 by the author. Licensee MDPI, Basel, Switzerland. This article is an open access article distributed under the terms and conditions of the Creative Commons Attribution (CC BY) license (http://creativecommons.org/licenses/by/4.0/). 